\title{
A dohányzásleszokás-támogatás első vonalbeli gyógyszeres terápiájának aktualitásai
}

\author{
Watti Jezdancher dr. - Mohos András dr., \\ Kelemen Oguz dr. - Pócs Dávid dr.
}

Szegedi Tudományegyetem, Általános Orvostudományi Kar, Magatartástudományi Intézet, Szeged

\begin{abstract}
A dohányzás jelenleg is az egyik legjelentősebb népegészségügyi probléma hazánkban. Az orvosi szakterületek többségében előkerül a dohányzásleszokás-támogatás kérdése. Ezért az orvostársadalom számára az aktuális gyógyszeres terápiás ismeretek összefoglalása hasznos lehet. A jelen közleményben a leszokástámogatás elsődlegesen választandó gyógyszeres terápiáját tekintjük át a legújabb összefoglalók és irányelvek szerint. A gyógyszeres lehetőségek közül jelenleg a vareniklin és a nikotinpótló terápia választandó elsóként, nemcsak a leszokás, hanem az ártalomcsökkentés tekintetében is. A legújabb kutatási eredmények szerint a kis dózisú vareniklin hatékonysága megközelíti a standard adagolás hatékonyságát, ugyanakkor kevesebb mellékhatás jelentkezik. A nikotinpótló kezeléssel kapcsolatban ki kell emelni, hogy egyre több tudományos evidencia áll a transdermalis és oralis készítmények kombinálása mellett, szemben a monoterápiával. A kis dózisú vareniklin, illetve a nikotinpótló terápia akkor is segítséget nyújt a naponta elszívott cigaretták mérséklésében, ha a kliens nem kíván leszokni, de a dohányzás ártalmait csökkentené. A nikotinerg rendszeren kívül más módon ható gyógyszerek szerepe is felmerült. Egyre több összefoglaló támogatja az antidepresszívumok használatát a nikotinfüggő́ség kezelésében. Ezek közül a bupropion használatával kapcsolatban van a legtöbb adat, amelyról tudjuk, hogy kombinálható a nikotinpótló terápiával és a vareniklinnel is. A gyógyszeres terápiát minden esetben tanácsos magatartásorvoslási módszerekkel, illetve adherenciát fokozó intervenciókkal kombinálni. Ezenkívül a szakellátási szint bevonása is javasolt, hogy a lehető legtöbb segítséget kapja meg a páciens a leszokáshoz.
\end{abstract}

Orv Hetil. 2021; 162(40): 1610-1618.

Kulcsszavak: dohányzás, dohányzásleszokás, dohányzásleszokást segítő hatóanyagok, nikotinpótló termékek, vareniklin

\section{Actualities in first-line pharmacotherapy for smoking cessation support}

Smoking is still one of the most significant public health problems in Hungary. The issue of smoking cessation support comes up in most medical specialties. Therefore, a summary of the current pharmacotherapeutic knowledge may prove useful to the medical community. In this paper, we review the first-line pharmacotherapy for smoking cessation based on the latest summaries and guidelines. Regarding the smoking cessation agents, varenicline and nicotine replacement therapy are currently the primary choice, not only in terms of cessation but also in terms of harm reduction. The results of previous studies suggest that the efficacy of low dose varenicline is close to that of standard dosing, with fewer side effects. With regard to nicotine replacement therapy, it should be emphasized that there is an increasing scientific evidence for the combination of transdermal and oral formulations as opposed to monotherapy. Low dose varenicline and nicotine replacement therapy also help reduce the number of cigarettes smoked daily if the client does not want to quit but would reduce the harms of smoking. The role of medications acting in other ways than the nicotinergic system has also emerged. An increasing number of reviews support the use of antidepressants in the treatment of nicotine addiction. Of these, most data are available on the use of bupropion, which is known to be combined with nicotine replacement therapy and varenicline. In all cases, it is advisable to combine pharmacotherapy with behavioral therapy as well as interventions that increase adherence. In addition, it is also recommended to include specific therapeutic interventions in order to get as much help as possible for the patient to quit smoking.

Keywords: smoking, smoking cessation, smoking cessation agents, nicotine replacement products, varenicline

Watti J, Mohos A, Kelemen O, Pócs D. [Actualities in first-line pharmacotherapy for smoking cessation support]. Orv Hetil. 2021; 162(40): 1610-1618.

(Beérkezett: 2021. február 21.; elfogadva: 2021. március 23.) 


\section{Rövidítések}

eGFR = (estimated glomerular filtration rate $)$ becsült glomerulusfiltrációs ráta; $\mathrm{MAO}=$ monoamin-oxidáz; $\mathrm{NRT}=$ (nicotine replacement therapy) nikotinpótló terápia; $\mathrm{OEP}=$ Országos Egészségbiztosítási Pénztár (ma Nemzeti Egészségbiztosítási Alapkezelő $) ;$ PAPA = (Perceptions and Practicalities Approach $)$ percepciókon és praktikumokon alapuló megközelítés

A dohányzás világszerte számos betegség közös rizikófaktoraként, valamint a korai halálozás egyik meghatározó tényezőjeként van jelen [1]. Az Egyesült Államokban évente több mint 435000 haláleset [2], Angliában pedig 82900 haláleset köthető a dohánytermékek fogyasztásához [3]. Magyarországon a felnőtt lakosság 27\%-a dohányzott az Eurobarometer 2017-ben végzett felmérésének adatai szerint [4]. A 2003-ban mért, 34\%-os csúcshoz képest a dohányzás prevalenciájának folyamatosan csökkenő tendenciája rajzolódik ki [4]. A 25-34 éves korcsoport kivételével, a férfiak körében csökkentek vagy változatlanok maradtak a rendszeresen dohányzók korcsoportos prevalenciái [4]. Az 55-64 éves korcsoport kivételével, a rendszeresen dohányzó nők aránya valamennyi korcsoportban csökkent [4]. Ennek ellenére a 35 és 70 év között elveszíthető életévek tekintetében a férfiaknál minden harmadik, a nőknél minden negyedik elvesztett életévet a nikotinfüggőség okozza Magyarországon [4].

A dohányzásleszokás-támogatás kétlépcsős folyamat [4]. Az első lépcső az úgynevezett minimálintervenció, amely az alapellátási szint. A második lépcső a szakellátási szint, amely a programszerü leszokás támogatásra utal [4]. Az alapellátási szint lépéseit a rövid és időtakarékos „3T” (angolul „3A”) minimálintervenció foglalja magában: a „tudakozódás” („Használ-e valamilyen dohányterméket?), a „tanácsadás” („Orvosi szempontból előnyös lenne Önnek a leszokás. Ha megengedi, elmondanék ezzel kapcsolatban néhány információt...”), végül a „tájékozódás” („Ezek ismeretében, le szeretne szokni?”) $[4,5]$. Ezen a szinten az egyik lehetőség, hogy a kliens elzárkózik a leszokástól. Ekkor a leszokási motiváció megerősítésére az „5R” módszert javasolja a leszokást támogató irányelv [4]. Ennek lényege, hogy az alábbi sorrendben, nyitott kérdésekkel feltárjuk a következő témaköröket: „risk/kockázat” („Ön szerint milyen összefüggés lehet a dohányzás és az egészségi állapota között? Milyen kockázatot jelenthet a dohányzás az Ön egészségére?”); „road-blocks/akadályok” („Mik a félelmei a leszokással kapcsolatban? Ön szerint milyen akadályokba ütközhet a leszokás alatt?”); „relevance/jelentőség” ( „Mit gondol, miért lehetne fontos a leszokás az Ön számára?”); „rewards/jutalom” („Milyen előnyei lehetnek a leszokásnak az Ön életében? Ezek közül melyek a legfontosabbak Önnek?") $[4,6]$. Ebben a rövid intervencióban fontos odafigyelni, hogy annak fókuszában a leszo- kás álljon, azaz szükség esetén a kérdésekkel mindig tereljük vissza a beszélgetést a leszokásra. Erre utal az „ötödik R”, a „repetition/ismétlés” [4, 6]. Ha a kliens az „5R” motivációs beszélgetés után is elzárkózik a leszokástól, tiszteletben kell tartani az autonómiáját és a döntését $[4,6]$. Ilyenkor a dohányzó kliens egészségmegőrzésének más formáira érdemes fókuszálni (például étrend, testmozgás, szűrővizsgálatok), hiszen a dohányzás miatt a kliens számos betegség tekintetében nagy rizikójúnak számít $[4,7]$. Későbbi találkozás alkalmával ismét használható a „3T” és szükség szerint az „5R” módszer $[4,7]$.

A másik lehetőség, ha a kliens nyitott a leszokásra. Ebben az esetben további két lépés kerül előtérbe: a „támogatás" (a leszokás viselkedésterápiás és gyógyszeres támogatása), illetve a „tevékenység ellenőrzése” (a viszszaesés megelőzése) [4]. Ezzel a két lépéssel egészülhet ki a korábban említett minimálintervenció, ennek együttes elnevezése „5T” (angolul „5A”) módszer [8]. A dohányzásleszokás támogatása és ellenőrzése már hoszszabb időszakot ölelhet fel, ami szakellátók bevonását teszi szükségessé. Magyarországon jelenleg a szakellátási szint a tüdőszürő állomásokon elérhető, az OEP által finanszírozott egyéni és csoportos leszokástámogató programokból, illetve az országosan bárhol elérhető, ingyenes, anonim telefonos tanácsadásból áll (06-80-4420-44) [4]. Emellett még javasolhatók internetes leszokástámogató felületek (például leteszemacigit.hu, CigiSzünet Facebook-oldal) [9], mobiltelefonos alkalmazások (például a „Gond? Egy szál se!” app) és nyomtatott önsegítő anyagok is (például az Országos Korányi Pulmonológiai Intézet szórólapjai). Sajnos az a mindennapi tapasztalat, hogy bár az alapellátó javasolja a szakellátási szint igénybevételét, a dohányzó betegek nem jelentkeznek ezeknél az ellátóknál. Ezért az alapellátóknak is érdemes bizonyos ismeretekkel rendelkezniük a viselkedésterápiás és gyógyszeres leszokástámogatással kapcsolatban $(5 \mathrm{~T} / 5 \mathrm{~A})$, hogy a „támogatás” és a „tevékenység ellenőrzése" az alapellátási és a szakellátási szinten párhuzamosan valósulhasson meg $[4,6]$. A magatartásorvoslási módszerek közül a „motivációs interjú” és a „kognitív viselkedésterápia” alkalmazására van a legtöbb evidencia a szakirodalomban $[10,11]$, részletes kifejtésük azonban meghaladja a jelenlegi közlemény terjedelmét, amely a gyógyszeres leszokástámogatás aktualitásait helyezi előtérbe. Korábban számos magyar közlemény született a leszokástámogató gyógyszerekról [12-14], ebben a munkában azonban a legújabb kutatások, öszszefoglalók és irányelvek szerint a jelenlegi, elsődlegesen választandó gyógyszeres terápiás lehetőségeket szeretnénk bemutatni. Fontos továbbá kiemelni, hogy a dohányzásleszokás-támogatás tekintetében a hazai irányelv a mérvadó [4], ezzel a közleménnyel csupán a gyógyszeres terápiát szeretnénk kiegészíteni, részletezni. 


\section{A gyógyszeres kezelés javallatai, ellenjavallatai}

A gyógyszeres terápia elsődleges célja a nikotinmegvonási tünetek mérséklése és ezáltal a nikotinfüggőség kezelése [15]. A megvonási tünetek alapvetően a rendszeres dohányzókra jellemzőek, akik naponta több mint 10 szál cigarettát szívnak el, illetve reggel, ébredést követően (azaz nikotinhiányos állapotban) egy órán belül rágyújtanak [15]. Tehát alkalmi dohányzóknál, akiknél megvonási tünetek nem alakulnak ki, a gyógyszeres terápia nem javasolt, számukra elegendőek a magatartásorvoslási módszerek [4, 15]. Ezzel szemben megvonási tüneteket produkáló (naponta több mint 10 szálat fogyasztó) dohányzók esetében a gyógyszeres kezelés indokolt, ugyanakkor az csak a magatartásorvoslás módszereivel együtt hatékony igazán [5]. Összegezve, a gyógyszer a nikotinfüggőség kezelésére használandó, míg a viselkedésterápia a pszichés tényezők kezelésére alkalmas $[4,15]$. Ez azt jelenti, hogy az alap- és szakellátóknak mindkét típusú támogatást érdemes ismerniük és alkalmazniuk [12]. Kiemelendő továbbá, hogy a megvonási tünetek nem csupán a dohányzás abbahagyásakor, hanem annak mérséklésekor is jelentkezhetnek [15]. Tehát „ártalomcsökkentés” esetén, azaz ha a kliens nem kíván leszokni, de szeretné csökkenteni dohányzási szokásainak ártalmait, akkor a naponta elszívott szálak csökkentése mellé javasolható számára gyógyszer [15]. Ebből adódóan a gyógyszeres kezelés célja a nikotinmegvonás kezelésén keresztül kettős: a leszokás és az ártalomcsökkentés segítése [15]. Fontos hangsúlyozni azt is, hogy nikotinmegvonási tünetek más dohánytermékek (például vízipipa, snüssz, IQOS ), illetve nikotintartalmú eszközök (például e-hose, Juul, e-cigaretta) használatát is kísérhetik [13]. Ezért a gyógyszeres terápia ezeknél a termékeknél is segítséget jelenthet a leszokásban és az ártalomcsökkentésben, megvonási tünetek esetén $[6,15]$.

A különböző gyógyszeres terápiák ajánlása függ a kliens nikotinfüggőségének mértékétől, életkorától (különös tekintettel a serdülőkre), várandósságától, illetve a társbetegségektől $[6,15]$. A serdülők, a várandós nők és a krónikus betegek gyógyszeres kezelésének elveivel külön fejezetben foglalkozunk. Egyes gyógyszerek dózisát a nikotinfüggőség mértéke határozhatja meg $[4,15]$. A különböző gyógyszerek között elsősorban a társbetegségeknek és a gyógyszerek mellékhatásprofiljának figyelembevételével lehet válogatni [6]. A lehetséges mellékhatások általában nem haladják meg a dohányzás folytatásának tulajdonítható egészségkockázatot [15]. A hatóanyagokkal vagy a segédanyagokkal szembeni túlérzékenységen kívül, önmagában a gyógyszeres kezelésnek más abszolút ellenjavallata nincs [6]. Kiemelendő azonban, hogy súlyos negatív életeseményeket követôen (például válás, munkahely elvesztése), illetve instabil pszichés állapotban (például középsúlyos vagy súlyos depressziós fázisban) a dohányzásleszokás nem javasolt
[4]. Ezért pszichiátriai betegek esetében előzetes pszichiátriai szakvizsgálat javasolt a leszokáshoz a szükséges stabil pszichés állapot megállapítása érdekében [15]. A gyógyszeres készítmények a hatékonyságukkal kapcsolatos evidenciák alapján két csoportra oszthatók; első vonalbeli gyógyszerekre (vareniklin, nikotinpótló terápia [nicotine replacement therapy - NRT ], bupropion) és másodvonalbeli gyógyszerekre [6, 15]. Közleményünkben az első vonalbeli készítményekkel foglalkozunk. Az első vonalbeli gyógyszerek mellett szóló érv továbbá a kevesebb mellékhatás, illetve hogy a gyógyszerhasználat ideje alatt csökkentik a leszokáshoz köthetó súlygyarapodást [15].

\section{Vareniklin}

A vareniklin a „nikotinreceptor parciális agonisták” csoportjába tartozik, ezért a központi idegrendszerben ugyanott hat, ahol dohányzáskor a nikotin, tehát a nikotinos acetil-kolin-receptorokon $(\alpha 4 \beta 2)$ [16]. Parciális agonista jellegéből adódóan hatása kettős. Egyrészt agonista, ezért leszokáskor enyhíti a nikotinmegvonási tüneteket, másrészt antagonista, ezért dohányzáskor közvetetten gátolja a mesolimbicus dopaminrendszer aktiválódását, azaz a dohányzáskor jelentkező ,jutalmat” (pozitív megerősítést) [16, 17]. A nikotinhoz képest intrinszik agonista aktivitása kisebb, ezért a vareniklin használatára jelentős tolerancia vagy hozzászokás nem jellemző [17]. A vareniklin vényköteles, felírása mind alapellátásban, mind szakellátásban lehetséges [4, 17]. Ellenjavallat hiányában elsőként választandó, hatékony és biztonságos gyógyszer, amelynek effektivitása meghaladja a másik két, első vonalbeli készítmény (a bupropion és az NRT) monoterápiás hatékonyságát [4, 15].

A vareniklin csak dohányzók számára javasolható, és viszonylag kevés esetben ellenjavallt: a ható- és segédanyaggal szembeni túlérzékenység; 18 év alatti életkor; várandósság és szoptatás $[15,17]$. Vareniklinkezelés során azonban különös figyelmet igényelnek a veseelégtelenségben szenvedő kliensek, a jármúvezetók, illetve a nehézgépkezelők [17]. Súlyos vesekárosodás esetén (eGFR $30 \mathrm{ml} / \mathrm{perc} / 1,73 \mathrm{~m}^{2}$ alatt) a kisebb dózisú vareniklinadagolás ajánlott [17]. A vareniklin a mellékhatásai miatt (például szédülés, aluszékonyság) hatással lehet a jármúvezetési vagy nehézgépkezelő képességre [17]. Ezért az ilyen tevékenységet rendszeresen végző klienseket figyelmeztetni kell arra, hogy a kezelés első heteiben ne vegyenek részt potenciálisan kockázatos feladatokban, illetve számukra is javasolható a kisebb dózisú adagolás [16, 17]. Mellékhatások hiányában a kezelés későbbi időszakában kellő óvatossággal végezhető ilyen tevékenység [17]. Korábban aggodalmak merültek fel a vareniklin neuropszichiátriai és cardiovascularis mellékhatásaival kapcsolatban is, a későbbi tanulmányok azonban nem támasztották alá ezeket a kérdéseket $[16,18]$. A vareniklin minimális mértékben metabolizálódik a májban, több mint 90\%-a változatlan formában ürül ki a 


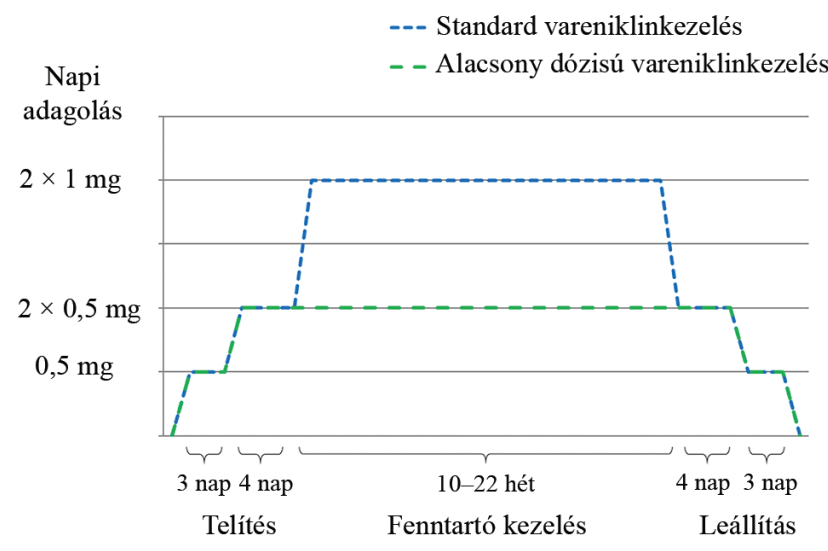

1. ábra

A vareniklin adagolása a standard és a kis dózisú kezelés szerint [15-17]

vizelettel, ezért májkárosodásban dózismódosítás nem szükséges [17, 18]. Továbbá kiemelendő, hogy egy randomizált kontrollált vizsgálat szerint a standard dózisú vareniklin előnyösnek bizonyult a dohányzásleszokás területén alkoholbetegek körében. Ugyanakkor felmerült, hogy az alkoholmegvonási tüneteket is csökkentheti dohányzók körében [19].

A vareniklin adagolási sémáit az 1 . ábrán foglaltuk öszsze, létezik egy standard és egy kis dózisú adagolás [1517]. A standard adagolás szerint a telítő dózist egy hét alatt kell titrálni ( 3 napig $1 \times 0,5 \mathrm{mg}$, majd 4 napig $2 \times$ $0,5 \mathrm{mg}$ ); ezalatt a dohányzás megengedett, és annak fokozatos csökkentése javasolt (ahogy korábban említettük, ilyenkor a dohányzás „jutalmazó” mechanizmusa gátlás alá kerül) [17]. A kezelés 8. napján ajánlott a dohányzás teljes elhagyása, és innentől a standard fenntartó dózis szerint $(2 \times 1 \mathrm{mg}$ dózisban) tanácsos szedni a vareniklint [17]. A kisebb dózisú adagolás esetében a titrálási időszak 3 napra rövidül $(1 \times 0,5 \mathrm{mg})$, majd a standard fenntartó dózist felezni kell $(2 \times 0,5 \mathrm{mg}$ vagy $1 \times 1 \mathrm{mg})$ [17]. A kétfajta adagolási sémát összehasonlító tanulmányok szerint a kis dózisú adagolás hatékonysága megközelíti a standard adagolás effektivitását, azonban jelentősen kevesebb mellékhatással jár (és a kezelés feleannyi financiális terhet ró a betegre) [16, 19]. Ezért mellékhatások jelentkezésekor (vagy financiális problémák esetén) a kisebb adagolás bátran ajánlható a betegeknek [16]. A javasolt kezelési időtartam mindkét adagolási séma esetén 3-6 hónap [15]. A további kezelést (relapsusprevenciót) illetően még nem áll rendelkezésre elegendó evidencia, bár tény, hogy egyes vizsgálatok 12 hónapos vareniklinkezelés mellett előnyöket észleltek a placebohasználathoz képest [16]. Ezenkívül ártalomcsökkentés céljából is javasolható egy 3 hónapos kezelés, elsősorban a kis dózisú adagolási séma szerint [17]. A vareniklinkezelést mindkét adagolási sémája esetén tanácsos a titrálási időszaknak megfelelően, fokozatosan elhagyni (például standard dózis esetén 4 napig felezett dózisban szedni, majd 3 napig ismét felezni a dózist) [17]. Mivel a vareniklinkezelés kezdeti időszakában a leggyakoribb mellék- hatás a hányinger és az émelygés, átmeneti adjuváns antiemetikumterápia mérlegelendő [19]. Ebben az esetben az ondanzetron az elsődlegesen választandó hányingercsillapító, mert feltehetően nincs interakció a két gyógyszer között [20].

\section{Nikotinpótló terápia}

Az NRT elve, hogy a szervezetbe juttatott nikotin által mérsékelje a megvonási tüneteket [4, 6, 15]. Ártalomcsökkentés esetén (amikor a kliens nem kíván leszokni, de csökkenteni szeretné szenvedélye egészségi ártalmait) a nikotinos acetil-kolin-receptorok száma változatlan marad: a szervezetbe juttatott nikotin egyik forrása a dohányzás, másik forrása a nikotinpótló készítmény [15, 21]. A dohányzással szemben minél nagyobb arányban használ valaki (kátránytól és más káros anyagoktól mentes) nikotinpótló készítményt, annál inkább képes csökkenteni az egészségi ártalmakat [22]. Ez a viselkedés fejleszti a kliens önkontrollképességét is, ami egy későbbi leszokási kísérletnél hasznosulhat [22]. A leszokás alatt a nikotinpótló készítmény dózisát fokozatosan csökkenteni kell: ezáltal a nikotinos acetil-kolin-receptorok száma is csökkenni, majd normalizálódni fog, ami a nikotinfüggôség megszûnéséhez vezethet $[15,21]$. Persze a fokozatos nikotincsökkentés más módon is elérhető (például a naponta elszívott cigaretták számának mérséklésével). Ám a megszokott nikotinbeviteli módszertől (például az inhalációtól) eltéró nikotinbeviteli eljárás hatékonyabbá teheti a leszokást (például a szájnyálkahártyán vagy bőrön keresztül) [23]. Továbbá a transdermalis nikotinbevitel során lassan és folyamatosan jut el a nikotin az agyba, ezért nem kötődik alkalmi „jutalom” (dopaminaktiváció) a használatához, ami csökkentheti a készítményhez való hozzászokás lehetőségét [24]. Kiemelendő, hogy a nikotinpótló készítményekkel kapcsolatos hozzászokás ritka, kevésbé káros, és könnyebb leszokni róluk, mint a dohányzásról [15]. Az NRT használata csak dohányzók számára ajánlott, és abszolút ellenjavallata a segédanyagokkal szembeni túlérzékenység, illetve a 12 év alatti életkor [21, 24]. A serdülők, várandósok, szoptató nők, illetve a kórházi kezelésben részesülő betegek nikotinpótló kezelésével kapcsolatban korlátozottak a rendelkezésre álló evidenciák, ezért ezekben a csoportokban alkalmazásuk fokozott óvatosságot igényel [4, 15]. Kiemelendő, hogy a nikotinbevitel során az acetilkolin-receptorokon keresztül a szimpatikus idegrendszer aktiválódhat $[15,21]$. Ezért a következményes cardiovascularis hatások (például vasospasmus, katecholaminfelszabadulás) veszélye miatt krónikus betegeknél számos relatív ellenjavallat felmerül (például ischaemiás stroke, instabil angina vagy myocardialis infarctus esetén) $[21,24]$. Kórházi kezelésben nem részesülő, stabil, panaszmentes krónikus betegekben a nikotinbevitel kisebb cardiovascularis kockázattal jár, ezért számukra az NRT valószínüsíthetően több előnyt jelenthet, mint a dohányzás folytatása [21, 24]. Ugyanakkor fontos azt is 
1. táblázat A 16 és a 24 órás nikotintapasz típusai a nikotinbeviteli sebesség alapján [15]

\begin{tabular}{lllll}
\hline & $0,3 \mathrm{mg} /$ óra & $0,6 \mathrm{mg} /$ óra & $0,9 \mathrm{mg}$ /óra & $1,6 \mathrm{mg}$ /óra \\
\hline 16 órás tapasz & $5 \mathrm{mg}$ & $10 \mathrm{mg}$ & $15 \mathrm{mg}$ & $25 \mathrm{mg}$ \\
24 órás tapasz & $7 \mathrm{mg}$ & $14 \mathrm{mg}$ & $21 \mathrm{mg}$ & \\
\hline
\end{tabular}

hangsúlyozni, hogy a nikotintúladagolás veszélye megfelelő, óvatos titrálással mérsékelhető [6]. Magyarországon a rövid hatású, oralis készítmények közül a gyógyszeres rágógumi, a szájnyálkahártyán alkalmazott spray és a szopogatótabletta, ezeken kívül a hosszú hatású transdermalis tapasz van jelenleg forgalomban [4]. Hatékonyságuk alapján a gyógyszeres leszokástámogatás első vonalbeli terápiái közé tartoznak $[4,15]$. Bár ezek a készítmények vény nélkül megvásárolhatók, az a tapasztalat, hogy a laikusok nincsenek tisztában ezek megfelelő alkalmazási módjával, ezért az orvosi tanácsadás a használatukkal kapcsolatban sokszor szükségszerú $[15,18]$.

A transdermalis tapasz előnye az NRT oralis készítményeivel szemben, hogy egyenletes nikotinkoncentrációt biztosít, ily módon célja a nikotinmegvonás gyakoriságának csökkentése $[15,23]$. Időtartam szerint kétféle, 16 és 24 órás transdermalis tapasz létezik $[4,6]$. A 16 órás transdermalis tapaszt elalvás előtt kell eltávolítani, így nem befolyásolja az alvásminőséget, de másnap reggel a kliens nikotinhiányos állapotban ébred [24]. Mivel transdermalis úton a nikotin 2-4 óra alatt éri el a szérumban a platószintet, a 16 órás transdermalis tapasz mellé reggel, megvonási tünetek esetén tanácsos gyors hatású, oralis készítményt is használni [15, 24]. A 24 órás transdermalis tapasz előnye, hogy reggel megfelelő nikotinszintet biztosít, hátránya, hogy alvászavart okozhat $[6,23]$. Az 1. táblázatban látható, hogyan felelhetnek meg egymásnak a 24 és a 16 órás transdermalis tapaszok a nikotinbeviteli sebesség szempontjából [15].
Például a $21 \mathrm{mg} / 24$ órás, illetve a $15 \mathrm{mg} / 16$ órás transdermalis tapasz egyaránt $0,9 \mathrm{mg}$ nikotint juttat a szervezetbe óránként [15].

A transdermalis tapaszra jellemző mellékhatás a bőrirritáció, melynek jelentkezésekor meg lehet változtatni a tapasz típusát, mivel a különböző gyártók különböző segédanyagokat használnak $[15,24]$. A rövid hatású, oralis nikotinpótló készítmények célja a megvonási tünetek akut kezelése [6, 23]. Míg transdermalis úton a felhasználók általában aluldozírozzák a nikotint, addig az oralis készítmények nem megfelelő használata során a túladagolás gyakoribb $[18,23]$. Az oralis nikotinbevitelt befolyásolja a szájüreg pH-értéke, ezért a felhasználónak tartózkodnia kell savas ételek és italok fogyasztásától 30 perccel az oralis NRT alkalmazása előtt [21]. Az oralis készítmények 1-4 mg-os kiszerelésekben érhetók el [4]. A túladagolás megelőzése érdekében érdemes a kisebb nikotintartalmú termékekkel kezdeni $[6,23]$. Ha a megvonási tünetek megjelenésekor egy kisebb nikotintartalmú készítmény nem szünteti meg a tüneteket, tanácsos abból még egy vagy két adagot használni, illetve később nagyobb nikotintartalmú oralis készítményre váltani $[6$, 23]. Ha egy nap alatt több mint 8-10 alkalommal használ a kliens oralis készítményt, a transdermalis nikotinbevitel emelése javasolt (nagyobb nikotintartalmú vagy egy újabb transdermalis tapasz használatával) [15].

A nikotinpótló készítmények kezdő dózisa, illetve a transdermalis tapaszok és az oralis készítmények kombinációjának szükségessége a nikotinfüggőoség mértékétől függ [23]. Ezzel kapcsolatban a 2. táblázatban látható egy összefoglaló az európai leszokástámogató irányelv ajánlása szerint [15]. Kutatások bizonyítják, hogy a transdermalis tapasz és az oralis nikotinpótló készítmények kombinálása sok esetben kedvezőbb lehet, mint egyetlen NRT-készítmény használata [15, 23]. A nikotinpótló kezelés adagolási sémáit a 2 . ábrán foglaltuk össze $[15,21,24]$. A terápiás siker szempontjából kulcs-

2. táblázat |A nikotinpótló terápia javasolt kezdeti dózisai [15]

\begin{tabular}{|c|c|c|c|c|}
\hline \multirow[t]{2}{*}{ A reggel elszívott első cigaretta ideje } & \multicolumn{4}{|c|}{ A naponta elszívott cigaretták száma } \\
\hline & $<10$ cigaretta/nap & 10-19 cigaretta/nap & 20-30 cigaretta/nap & $>30$ cigaretta/nap \\
\hline$<$ Felkelés után 5 perccel & & $\begin{array}{l}\text { Nagy dózisú tapasz } \\
(0,9 \mathrm{mg} / \mathrm{h}) \\
\pm \text { NRT oralis formái }\end{array}$ & $\begin{array}{l}\text { Nagy dózisú tapasz } \\
(0,9 \mathrm{mg} / \mathrm{h}) \\
\pm \text { NRT oralis formái }\end{array}$ & $\begin{array}{l}2 \text { nagy dózisú tapasz } \\
(1,8 \mathrm{mg} / \mathrm{h}) \\
\pm \text { NRT oralis formái }\end{array}$ \\
\hline <Felkelés után 30 perccel & & $\begin{array}{l}\text { Nagy dózisú tapasz } \\
(0,9 \mathrm{mg} / \mathrm{h})\end{array}$ & $\begin{array}{l}\text { Nagy dózisú tapasz } \\
(0,9 \mathrm{mg} / \mathrm{h}) \\
\pm \text { NRT oralis formái }\end{array}$ & $\begin{array}{l}\text { Nagy dózisú tapasz } \\
(0,9 \mathrm{mg} / \mathrm{h}) \\
\pm \text { NRT oralis formái }\end{array}$ \\
\hline <Felkelés után 60 perccel & $\begin{array}{l}\text { Gyógyszerhasználat nem } \\
\text { javasolt }\end{array}$ & NRT oralis formái & $\begin{array}{l}\text { Nagy dózisú tapasz } \\
(0,9 \mathrm{mg} / \mathrm{h})\end{array}$ & $\begin{array}{l}\text { Nagy dózisú tapasz } \\
(0,9 \mathrm{mg} / \mathrm{h}) \\
\pm \text { NRT oralis formái }\end{array}$ \\
\hline >Felkelés után 60 perccel & $\begin{array}{l}\text { Gyógyszerhasználat nem } \\
\text { javasolt }\end{array}$ & $\begin{array}{l}\text { Gyógyszerhasználat nem } \\
\text { javasolt }\end{array}$ & NRT oralis formái & \\
\hline Nem napi szintű dohányzó & $\begin{array}{l}\text { Gyógyszerhasználat nem } \\
\text { javasolt }\end{array}$ & $\begin{array}{l}\text { Gyógyszerhasználat nem } \\
\text { javasolt }\end{array}$ & & \\
\hline
\end{tabular}

NRT = nikotinpótló terápia 
- 1. példa: NRT adagolása, ha az induló dózis megvonási tüneteket okoz - - 2. példa: NRT adagolása, ha az induló dózis optimális

--- 3. példa: NRT adagolása, ha az induló dózis túladagoláshoz vezet

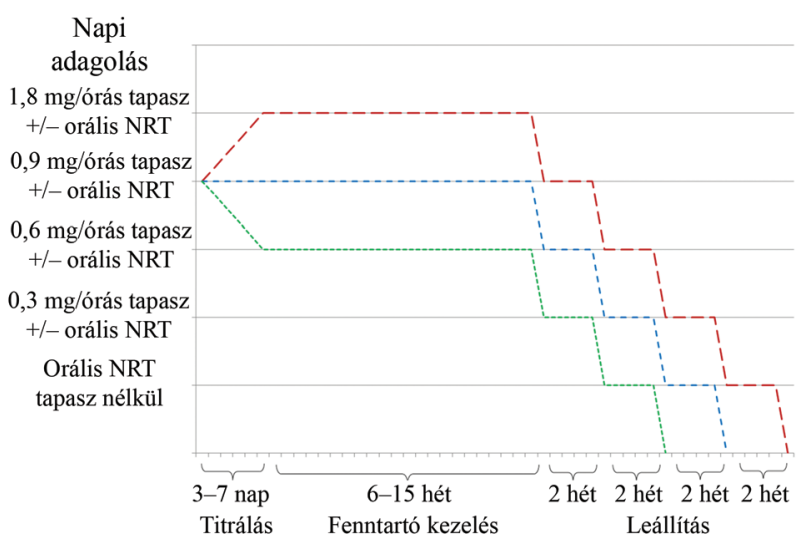

2. ábra

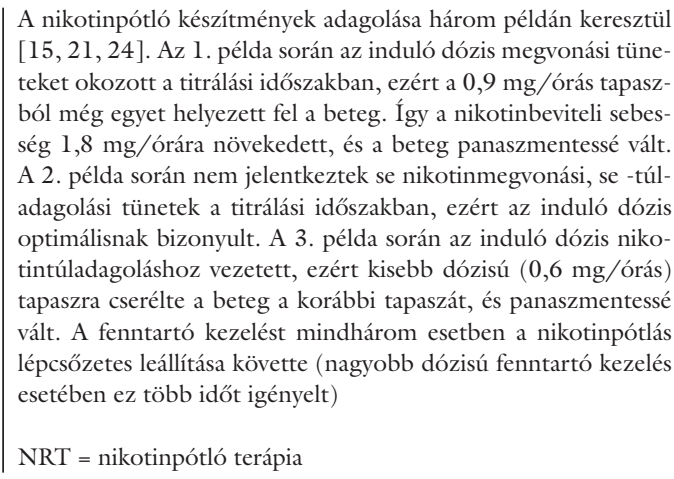

fontosságú a minimum 3 napos, kezdeti titrálási időszak $[15,21]$. Ebben a kritikus időszakban sok kliens azért hagyja abba a kezelést, mert nem visz be elegendő nikotint a szervezetébe (és megvonási tünetei felerősödnek), vagy épp ellenkezőleg, túladagolja a nikotint $[6,15]$. Ezért a megfelelő edukáció és az adherencia kardinális kérdés a terápia kezdetén, mert a kliensnek kell felismernie a túladagolást vagy a megvonási tüneteket és módosítania a nikotinbevitel dózisát [15]. Túladagolás esetén azonnal fel kell függeszteni a nikotinbevitelt, a transdermalis tapasz helyét vízzel lemosni és megszárítani (szappan nem használható, mert elősegíti a felszívódást) [24]; oralis készítmény túladagolásakor aktív szén csökkentheti az emésztőrendszeri felszívódást [21]. A nikotinbevitel titrálása szempontjából nagy az egyéni variancia: sok esetben igen nagy dózisú készítményekre lehet szükség, de a túladagolási és a megvonási tünetek ezt az egyéni tartományt jól behatárolják [15, 23]. Mivel a nikotin a májban metabolizálódik és a vesén keresztül ürül, máj- és vesekárosodás esetén a kezdő dózis csökkentése és óvatos titrálás indokolt $[21,24]$. A 2. táblázatban látható kezdő dózis a leszokásra vonatkozik, ebben az esetben a dohányzást fel kell függeszteni [15]. Ártalomcsökkentés esetén a kliens dohányzás mellett használ valamilyen nikotinpótló készítményt, ebben az esetben értelemszerüen kisebb kezdő dózis használandó [22]. Titrálást követően a kliens által optimálisnak tartott nikotinbeviteli dózis 6 hétig alkalmazandó $[21,24]$. Leszokás esetén ezt követően fokozatosan tanácsos csökkenteni a nikotin dózisát: először egyre kisebb dózisú tapaszra kell váltani 2 hetente (21-14-7 mg, illetve 25-15-10-5 mg), majd az oralis készítményeket is el kell hagyni fokozatosan a kliens igényei szerint (4-2-1,5-1 mg) [21, 24]. A nikotinbevitel fokozatos csökkentése általában 8-12 héten keresztül tart, ugyanakkor a terápia meghosszabbítható 6 hónapig, ami még inkább növelheti az absztinenciarátát $[15,23]$.

\section{Bupropion}

A bupropion egy antidepresszívum, mely végeredményben a nikotinbevitelhez hasonló hatást fejt ki azáltal, hogy növeli a szervezetben a dopamin- és a noradrenalinszintet [25]. Ily módon csillapíthatja a nikotinmegvonási, illetve a következményes depressziós tüneteket [15]. Ez a hatásmechanizmus rávilágít arra, hogy a rendszeres dohányzás a nikotinbevitelen keresztül egyfajta hangulatjavító hatást okoz, ami indokolttá teszi bizonyos antidepresszívumok alkalmazását $[15,25]$. Úgy tünik, hogy más antidepresszívumokkal összehasonlítva a bupropion a nikotinfüggőség szempontjából különálló sajátsággal bír, mivel a dohányzás abbahagyásával kapcsolatos pozitív hatása a nem depressziós betegek esetében is bizonyított [6, 15]. Magyarországon azonban (számos más országgal szemben) a bupropion jelenleg nincs törzskönyvezve dohányzásleszokás-támogatási javallattal $[4,26]$. A bupropion ellenjavallt 18 év alatt; várandósság vagy szoptatás idején; illetve a hatóanyaggal vagy a segédanyagokkal szembeni túlérzékenység esetén $[25,26]$. Mivel a bupropion fokozza a görcstevékenységet, további ellenjavallat az epilepszia, a görcstevékenységre hajlamosító betegségek (fejsérülés, idegrendszeri daganatok, alkoholizmus stb.) és hajlamosító gyógyszerek (például nyugtatók szedése, megvonása), illetve a súlyos májelégtelenség és a MAO-gátlók használata [26]. Idős személyeknél, valamint súlyos vese- vagy májkárosodás esetén a bupropion dózisának a felére történő csökkentése tanácsos $[25,26]$. Jármúvezetők és nehéz-

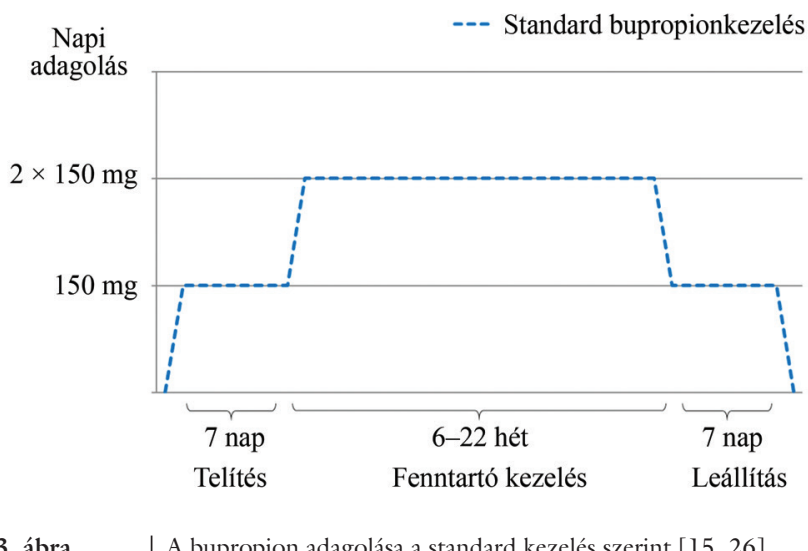

3. ábra $\mid$ A bupropion adagolása a standard kezelés szerint $[15,26]$ 
gépkezelők esetében javasolják a bupropion mellékhatásainak előzetes ellenőrzését, mivel szédülést, csökkent koncentrációs képességet okozhat [26]. A kezdeti dózis $150 \mathrm{mg}$, szükség esetén $2 \times 150 \mathrm{mg}$-ra emelhető [ 15 , 26] (3. ábra). Mivel az insomnia a bupropion gyakori mellékhatása, az első tablettát reggel, a másodikat 8 órával később érdemes bevenni (például reggel 8 és délután 4 órakor), nem pedig lefekvés előtt [26]. Továbbá a mellékhatások mérsékelhetők retard készítmény használatával [25]. Más antidepresszívumokhoz hasonlóan a gyógyszer hatása hetek alatt alakul ki, ezért a dohányzás abbahagyása előtt legalább 2 héttel érdemes elkezdeni a szedését $[15,26]$. A javasolt kezelési időtartam 2-6 hónap [27]. A bupropion kombinálható NRT-vel és vareniklinnel [15]. Ezzel kapcsolatban még kevés evidencia áll rendelkezésre, az eddigi eredmények azonban biztatóak $[15,25]$.

\section{Speciális populációk}

Ahogyan azt korábban is említettük, nikotinmegvonási tünetek a nikotintartalmú eszközök (például e-hose, Juul, e-cigaretta) használatát is kísérhetik, ezért a gyógyszeres kezelés ebben az esetben is felmerül [13]. Fontos hangsúlyozni, hogy az ilyen termékek használata nem tekinthető kockázatmentesnek [28], illetve nagyobb addiktív potenciáljuk miatt nem javasoltak a dohányzásleszokás támogatására [29]. A vareniklin és az NRT a megvonási tüneteket produkáló, nikotintartalmú eszközt használók körében is jó választás lehet, a megfelelő dózis kiválasztására azonban még nincs kellő mennyiségû adat $[6,15]$. Ezért kis dózisú vareniklinadagolás, illetve a nikotinpótló készítmények óvatos titrálása javasolt.

A 12 évnél fiatalabb gyermekek esetében a dohányzás nem jellemző, ezért ebben az életkorban általában a gyógyszeres kezelés sem jön szóba [15]. Serdülők, illetve várandós nők leszokástámogatása során törekedni kell a gyógyszeres terápia elkerülésére a magatartásorvoslási módszerek intenzívebb használata révén [4, 15]. Amenynyiben ez nem lehetséges vagy eredménytelen, elsősorban az NRT alkalmazható, hiszen a leszokás egészségi előnyei feltételezhetően meghaladják a nikotinpótlás kockázatait (és más gyógyszer használatáról még nincs elegendő evidencia ezekben a populációkban) [30, 31]. A nikotinpótló kezelés alatt serdülők esetében a szülők [30], várandós nók esetén a gondozó szülészorvos bevonása természetesen elengedhetetlen [31]. Azoknak a serdülőknek, illetve várandós nóknek, akik elzárkóznak a dohányzásleszokástól, ártalomcsökkentési javallattal is ajánlható nikotinpótló készítmény [22]. A várandósokra vonatkozó ajánlások a gyermekvállalás időszakára, illetve a post partum időszakra is vonatkoznak, hiszen a leszokás előnyei a nikotinpótlás kockázatai mellett is felülmúlják a dohányzás veszélyeit a magzat vagy az újszülött tekintetében [31]. Fontos kiemelni továbbá, hogy azoknál a dohányzó, szoptató nőknél, akik elzárkóznak a leszo- kástól és az ártalomcsökkentéstől is, javasolt a szoptatás, mivel az anyatej az újszülött számára ellensúlyozhatja a cigarettafüst károsító hatásait [32]. Egy tanulmány szerint ugyanis az akut légzőszervi megbetegedések veszélye kisebbnek bizonyult azoknál a csecsemóknél, akiket dohányzó édesanyjuk szoptatott, mint azoknál, akik tápszeres táplálásban részesültek [32]. Mivel a szoptatás egészségi előnyei a nikotinpótló kezelés kockázatait is ellensúlyozzák, az a szoptatás alatt is ajánlott abban az esetben, ha a magatartásorvoslási módszerek önmagukban sikertelenek vagy nem kivitelezhetők [33].

A gyógyszeres leszokástámogatás egy másik speciális csoportját az akut, illetve a krónikus betegek alkotják. Diagnózistól függetlenül, a hospitalizáció alatt elkezdett nikotinpótló kezelés növeli a sikeres leszokást, ha legalább 1 hónapig nyomon követik és támogatják a betegeket az emittálást követően, illetve azt magatartásorvoslási módszerekkel kombinálják [34]. Ez tehát akut és krónikus betegekre egyaránt vonatkozik, néhány országban rutinszerü beavatkozás [15]. A hospitalizáció alatt kezdeményezett leszokástámogatás kapcsán a vareniklin használatára kevés evidencia áll rendelkezésre, de pozitív hatása feltételezhető [16]. Az antidepresszívumok ezen a területen kevésbé alkalmazhatók többhetes hatásbeállásuk miatt [34]. A gyógyszeres kezelések a prehospitális időszakban is hatékonynak bizonyultak [35]. Elektív mútétek esetében, ha a nikotinpótló kezelést legalább 4 héttel a mütét előtt elkezdték, és magatartásorvoslási módszerekkel kombinálták, az szignifikánsan növelte a hosszú távú, sikeres leszokás esélyét, valamint csökkentette a posztoperatív szövődmények kialakulását [35]. A vareniklin használatáról a preoperatív leszokástámogatással kapcsolatban is kevés bizonyíték áll rendelkezésre [35]. A leszokás előnyei természetesen jelentősen meghaladják annak lehetséges kockázatait a krónikus betegek esetében is [15]. Ám körültekintően, a fentiekben részletesen ismertetett, relatív ellenjavallatok szerint kell megválasztani a leszokást segítő gyógyszert a különböző krónikus betegségekben $[4,15]$. Kiemelendő továbbá, hogy a leszokás során a regulárisan szedett gyógyszerek metabolizmusa változhat, ezért azok dózismódosítása válhat szükségessé, ami a terápiás végpontok (például vérnyomás, vércukor, laborértékek) szorosabb nyomon követését is igényelheti $[4,15]$.

\section{Leszokást segítő gyógyszerek és az adherencia}

Fontos hangsúlyozni, hogy a gyógyszerek hatékonyságát igazoló randomizált, kontrollált vizsgálatok szigorú ellenőrzés mellett érvényesek, tehát magas szintü adherenciát feltételeznek [15]. A valós életből vett minták szerint azonban a dohányzók nem az elrendelt dózisban vagy időtartamban szedik ezeket a gyógyszereket [36]. Mivel a dohányzást gyógyszer nélkül is abba lehet hagyni, a leszokást segítő gyógyszerek terápiás jelentőségét sok laikus megkérdőjelezi, a mellékhatásokat felnagyítják 
vagy túlértékelik, illetve számos tévhit él ezzel kapcsolatban [36]. Ezért az adherencia fokozására kidolgozott PAPA (Perceptions And Practicalities Approach) módszer két területre fókuszál: a „percepciókra” (tévhitekre, aggodalmakra, elvárásokra), azaz „miért érdemes gyógyszert szednie a betegnek”, valamint a „praktikumokra” (szükséges erőforrásokra, készségekre, illetve az akadályok megoldására), azaz „hogyan lehet növelni a gyógyszerszedés hatékonyságát” [37]. Fontos megemlíteni azt is, hogy a gyógyszerszedéssel kapcsolatos rutintájékoztatás alapvetően az ellátáshoz tartozik, míg az adherenciát fokozó intervenciók ezenfelül megtett erőfeszítések, és kiegészítik az átlagos terápiás tájékoztatást $[36,37]$. Az adherencia monitorozásában a számszerúsíthető, objektív adatok az irányadók (például egy adott kezelési időszak alatt elfogyasztott gyógyszer mennyisége vagy a megfelelő gyógyszerszedés napjainak száma), szemben a szubjektív adatokkal (például a beteg ismeretei, attitüdjei) [36]. A nyomon követés eszközei lehetnek bizonyos elektronikus méróeszközök (például gyógyszerszedési applikációk), önbevallásos kérdőívek, illetve a gyógyszerkészítmények megszámolása harmadik személy által [36]. Mivel a nikotinpótló készítmények vény nélkül kaphatók, használatuk során kiemelt jelentőséggel bír az adherencia [37]. Ezért a leszokást támogató gyógyszerek adherenciájával kapcsolatos kutatások többsége is a nikotinpótló készítményekkel foglalkozott [36]. Összefoglalva az eredményeket, egyelőre kevés evidencia áll rendelkezésre annak eldöntésére, hogy ezek az intervenciók valóban növelik-e a gyógyszerszedési adherenciát, illetve a tartós leszokás esélyét [36]. Továbbá meg kell említeni azt is, hogy a magatartásorvoslási programban részesülók gyógyszerszedési adherenciájának rátája viszonylag jó $[15,37]$. Ezért az adherenciát fokozó beavatkozásokra elsősorban olyan helyzetekben és olyan betegcsoportokban van szükség, amelyeknél az adherencia valószínúleg alacsony (például leszokástámogató szakellátásban nem részesülők körében vagy többszörös relapsus esetén) [36].

\section{Zárógondolatok}

Összefoglaló tanulmányunkban a legújabb kutatások és irányelvek szerint a dohányzásleszokás-támogatás elsó vonalbeli gyógyszeres terápiás lehetőségeit, javallatait, ellenjavallatait és adagolási sémáit mutattuk be. Az ellenjavallatok függvényében a vareniklin és az NRT választandó elsőként a gyógyszeres leszokástámogatás lehetőségei közül [4, 15]. Fontos hangsúlyozni, hogy a nikotinpótló készítmények kombinációja hatékonyabbnak bizonyult, mint a nikotinpótló monoterápia $[6,23]$. A nikotinos acetil-kolin-receptoron ható vegyületeken kívül, a dohányzás antidepresszív hatása miatt, egyre nagyobb figyelem irányul az antidepresszívumokra a nikotinfüggőség kezelésében [15]. Ezek közül a bupropion a kevesebb mellékhatással rendelkező, első vonalbeli gyógyszer, mely kombinálható NRT-vel és vareniklinnel
[15, 25]. A gyógyszeres terápiát minden esetben érdemes magatartásorvoslási módszerekkel kombinálni [4, 15]. Kiemelendő továbbá, hogy a terápiás adherenciát növelő intervenciók is hozzájárulhatnak a leszokás sikeréhez (például a terápiával kapcsolatos elvárások, tévhitek, aggodalmak feltárása és tisztázása) [36, 37].

Anyagi támogatás: A közlemény megírása anyagi támogatásban nem részesült.

Szerzői munkamegosztás: W. J., P. D.: A téma felvetése. W. J., M. A., K. O., P. D.: A kézirat megszövegezése. A cikk végleges változatát valamennyi szerző elolvasta és jóváhagyta.

Érdekeltségek: A szerzőknek nincsenek érdekeltségeik.

\section{Irodalom}

[1] Jamison DT, Breman JG, Measham AR, et al. Disease control priorities in developing countries. 2nd edition. Oxford University Press, New York, NY, 2006.

[2] Fiore MC, Jaén CR, Baker TB, et al. Treating tobacco use and dependence: 2008 update. Quick reference guide for clinicians. U.S. Department of Health and Human Services, Public Health Service, Rockville, MD, May 2008.

[3] World Health Organization, Regional Office for Europe. European health for all database. WHO, Copenhagen, 2010. Available from: https://www.euro.who.int/en/data-and-evidence/ archive/european-health-for-all-database-hfa-db [accessed: February 12,2021 ].

[4] Hungarian Ministry of Human Resources. National guideline of smoking cessation support. [Az Emberi Eróforrások Minisztériuma egészségügyi szakmai irányelve a dohányzásról való leszokás támogatásáról.] Budapest, 2019. Available from: https://tudogyogyasz.hu/Media/Download/12698 [accessed: February 12, 2021]. [Hungarian]

[5] Park ER. Behavioral approaches to smoking cessation. 2020. Available from: https://www.uptodate.com/contents/behavioral-approaches-to-smoking-cessation [accessed: February 12, $2021]$.

[6] Rigotti NA. Pharmacotherapy for smoking cessation in adults. 2021. Available from: https://www.uptodate.com/contents/ pharmacotherapy-for-smoking-cessation-in-adults [accessed: February 12, 2021].

[7] Chandler MA, Rennard SI. Smoking cessation. Chest 2010; 137: $428-435$.

[8] Lawson PJ, Flocke SA, Casucci B. Development of an instrument to document the 5A's for smoking cessation. Am J Prev Med. 2009; 37: 248-254.

[9] Pócs D, Kovács R, Óvári T, et al. Tobacco reduction on Facebook among 14-35-year-olds. [A dohányzás visszaszorítása a Facebook segítségével a 14-35 éves korosztály körében.] Orv Hetil. 2019; 160: 220-227. [Hungarian]

[10] Lancaster T, Stead LF. Individual behavioural counselling for smoking cessation. Cochrane Database Syst Rev. 2017; 3: CD001292.

[11] Pócs D, Hamvai Cs, Kelemen O. Health behavior change: motivational interviewing [Magatartás-változtatás az egészségügyben: a motivációs interjú.] Orv Hetil. 2017; 158: 1331-1337. [Hungarian]

[12] Szendi A. Pharmacotherapeutic support for smoking cessation: opportunities for the pharmacist. [A dohányzásról történő leszo- 
kás gyógyszeres támogatása: a gyógyszerész lehetőségei.] Gyógyszerészet 2015; 59: 271-280. [Hungarian]

[13] Friederich HM, Batra A. Pharmacotherapeutic support for smoking cessation. [A dohányzásról való leszokás gyógyszeres támogatása.] Orvostovábbk Szle. 2010; 17(12): 77-81. [Hungarian]

[14] Reismann P, Tulassay Zs. Pharmacotherapeutic aid for smoking cessation. [A dohányzásról való leszokás gyógyszeres segítése.] Magy Belorv Arch. 2009; 62: 15-20. [Hungarian]

[15] European Network for Smoking and Tobacco Prevention. ENSP guidelines for treating tobacco dependence. Brussels, 2016. Available from: http://elearning-ensp.eu/assets/English\%20 version.pdf [accessed: February 12, 2021].

[16] Cahill K, Lindson-Hawley N, Thomas KH, et al. Nicotine receptor partial agonists for smoking cessation. Cochrane Database Syst Rev. 2016; 5: CD006103.

[17] National Institute of Pharmacy and Nutrition. Champix 0,5 mg; Summary of product characteristics. [Országos Gyógyszerészeti és Élelmezés-egészségügyi Intézet. Champix $0,5 \mathrm{mg}$; Alkalmazási előírás.] Available from: https://ogyei.gov.hu/gyogyszeradatbazis\&action $=$ show_details\&item $=31343$ [accessed: February 12, 2021]. [Hungarian]

[18] Rigotti NA. Overview of smoking cessation management in adults. 2021. Available from: https://www.uptodate.com/contents/overview-of-smoking-cessation-management-in-adults [accessed: February 12, 2021].

[19] Hurt RT, Ebbert JO, Croghan IT, et al. Varenicline for tobaccodependence treatment in alcohol-dependent smokers: a randomized controlled trial. Drug Alcohol Depend. 2018; 184: 12-17.

[20] Ortiz NC, O’Neill HC, Marks MJ, et al. Varenicline blocks $\beta 2$ * nAChR-mediated response and activates $\beta 4^{*}$-nAChR-mediated responses in mice in vivo. Nicotine Tob Res. 2012; 14: 711-719.

[21] National Institute of Pharmacy and Nutrition. Niquitin Minitab 1,5 mg; Summary of product characteristics. [Országos Gyógyszerészeti és Élelmezés-egészségügyi Intézet. Niquitin minitab 1,5 mg; Alkalmazási elóírás.] Available from: https://ogyei.gov. hu/gyogyszeradatbazis\&action $=$ show_details\&item $=27297$ [accessed: February 12, 2021]. [Hungarian]

[22] Lindson-Hawley N, Hartmann-Boyce J, Fanshawe TR, et al. Interventions to reduce harm from continued tobacco use. Cochrane Database Syst Rev. 2016; 10: CD005231.

[23] Hartmann-Boyce J, Chepkin SC, Ye W, et al. Nicotine replacement therapy versus control for smoking cessation. Cochrane Database Syst Rev. 2018; 5: CD000146.

[24] National Institute of Pharmacy and Nutrition. Nicorette Patch $25 \mathrm{mg} / 16 \mathrm{~h}$; Summary of product characteristics. [Országos Gyógyszerészeti és Élelmezés-egészségügyi Intézet. Nicorette Patch $25 \mathrm{mg} / 16$ óra; Alkalmazási eloórás.] Available from: https://ogyei.gov.hu/gyogyszeradatbazis\&action=show details\&item $=27696$ [accessed: February 12, 2021]. [Hungarian]
[25] Howes S, Hartmann-Boyce J, Livingstone-Banks J, et al. Antide pressants for smoking cessation. Cochrane Database Syst Rev. 2020; 4: CD000031.

[26] National Institute of Pharmacy and Nutrition. Elontril $300 \mathrm{mg}$; Summary of product characteristics. [Országos Gyógyszerészeti és Élelmezés-egészségügyi Intézet. Elontril 300 mg; Alkalmazási elöírás.] Available from: https://ogyei.gov.hu/gyogyszeradatbazis\&action $=$ show_details\&item $=24331$ [accessed: February 12, 2021]. [Hungarian]

[27] Richmond R, Zwar N. Review of bupropion for smoking cessation. Drug Alcohol Rev 2003; 22: 203-220.

[28] Farkas A, Tomisa G, Kis E, et al. Health effects of cigarettes, electronic cigarettes and waterpipes. [A cigaretta, az elektromos cigaretta és a vízipipa egészségre gyakorolt hatása.] Orv Hetil. 2021; 162: 83-90. [Hungarian]

[29] Cselkó Zs, Pénzes M. Summary of the existing knowledge about electronic cigarettes. [Az elektronikus cigarettáról meglévő ismeretek összefoglalása.] Orv Hetil. 2016; 157: 979-986. [Hungarian]

[30] Pócs D, Barabás K, Kelemen O. Interventions in medical practice to reduce tobacco use among adolescents. [Intervenciók az orvosi gyakorlatban a serdülókori dohányzás visszaszorítására.] Orv Hetil. 2018; 159: 593-602. [Hungarian]

[31] Rodriguez D. Tobacco and nicotine use in pregnancy: cessation strategies and treatment options. 2021. Available from: https:// www.uptodate.com/contents/cigarette-smoking-in-pregnancycessation-strategies-and-treatment-options [accessed: February $12,2021]$.

[32] Woodward A, Douglas RM, Graham NM, et al. Acute respiratory illness in Adelaide children: breast feeding modifies the effect of passive smoking. J Epidemiol Community Health 1990; 44: 224-230.

[33] American Academy of Pediatrics, Committee on Drugs. Transfer of drugs and other chemicals into human milk. Pediatrics 2001; 108: 776-789.

[34] Rigotti NA, Clair C, Munafò MR, et al. Interventions for smoking cessation in hospitalised patients. Cochrane Database Syst Rev. 2012; 5: CD001837.

[35] Thomsen T, Villebro N, Møller AM. Interventions for preoperative smoking cessation. Cochrane Database Syst Rev. 2014; 3 : CD002294.

[36] Hollands GJ, Naughton F, Farley A, et al. Interventions to increase adherence to medications for tobacco dependence. Cochrane Database Syst Rev. 2019; 8: CD009164.

[37] Horne R, Chapman SC, Parham R, et al. Understanding patients' adherence-related beliefs about medicines prescribed for long-term conditions: a meta-analytic review of the NecessityConcerns Framework. PLoS ONE 2013; 8: e80633.

(Watti Jezdancher dr., Szeged, Szentháromság u. 5., 6722 e-mail: yezdanser.watti@gmail.com)

A cikk a Creative Commons Attribution 4.0 International License (https://creativecommons.org/licenses/by/4.0/) feltételei szerint publikált Open Access közlemény, melynek szellemében a cikk bármilyen médiumban szabadon felhasználható, megosztható és újraközölhetö, feltéve, hogy az eredeti szerző és a közlés helye, illetve a CC License linkje és az esetlegesen végrehajtott módositások feltüntetésre kerülnek. (SID_1) 